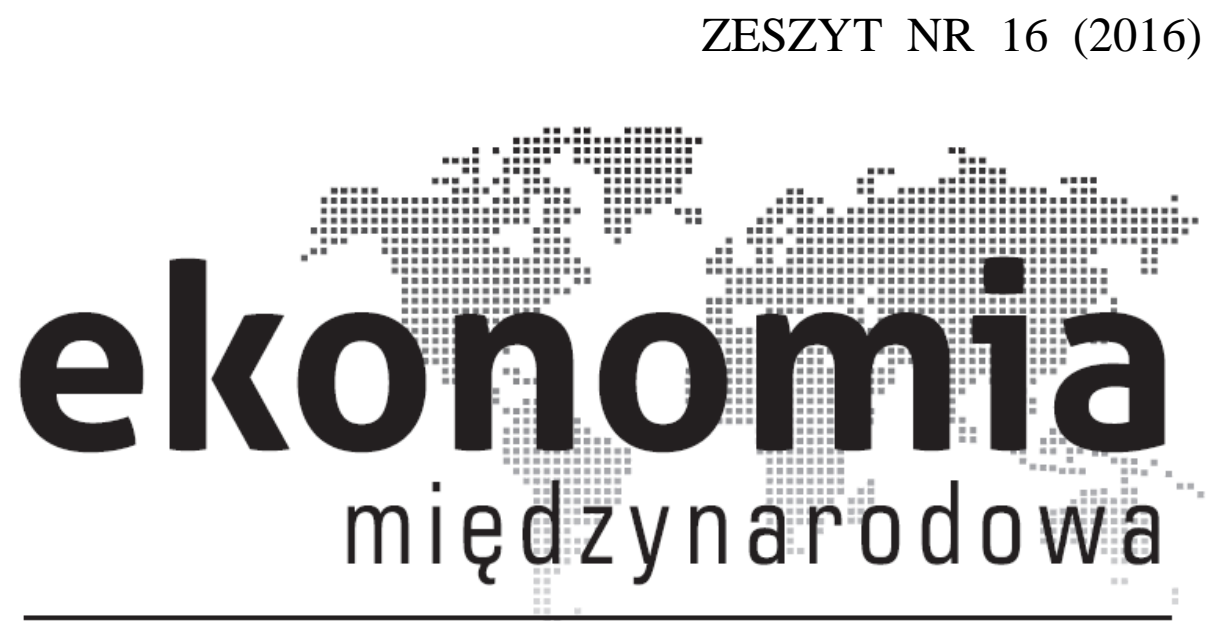

Ekonomia Międzynarodowa

Nr 16 (2016)

www.ekonomia-m.pl

ISSN: 2082-4440

EISSN: 2300-6005

Wydawca: Uniwersytet Łódzki

Wersja elektroniczna czasopisma jest wersją referencyjną
Publisher: University of Lodz

Electronic edition is the reference version of the journal
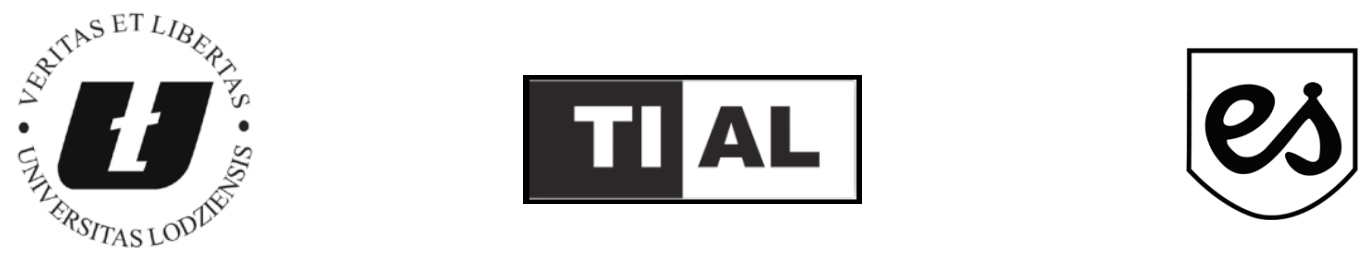


\section{On the Causes of the Eurozone Crisis}

Tomasz Serwach*

\section{Introduction}

The Eurozone crisis seems to be one of the most important economic events since the foundation of the currency union. Being a non-optimal (sub-optimal at best) currency area plagued by a lack of leadership and prolonged decision making, the Eurozone was thought by many to be on the brink of collapse. Although the risk of full or even partial disintegration did not materialize, many problems are yet to be solved and not all flaws have been removed.

Almost all European Union countries have signed the Fiscal Pact, troubled economies have follow the path of austerity, the European Central Bank has provided much needed liquidity, and supervision of the financial sector has been extended. However, it remains to be seen whether those steps will reduce the risk of future crises or at least provide the Eurozone with efficient shock absorbers. Unfortunately, some of those actions aim at fighting non-existent enemies. For example, much pressure has been put on periphery countries to force them to improve their fiscal position. Yet, the evidence that excessive budget deficits or public debts are at the root of the crisis can hardly be seen.

In order to implement adequate measures, it is necessary to have a good diagnosis of the situation. That diagnosis must point out the fundamental reasons of the Eurozone crisis. Following the economic growth literature, I present and analyze proximate and fundamental causes of the crisis. The former include both fiscal (budget balance, public debt) and balance of payments (current account balance) factors. The latter contain determinants of international competitiveness and capital flows. Within the fundamental causes I focus on those affecting balance of payments only because - as I will present - the fiscal positions of Eurozone members cannot be responsible for the crisis.

\footnotetext{
* Tomasz Serwach - doktor nauk ekonomicznych, Uniwersytet Łódzki, Wydział Ekonomiczno-
} -Socjologiczny, Katedra Wymiany Międzynarodowej 
To the best of my knowledge, existing studies are one-dimensional in their focus on competitiveness or capital flows. Researchers tend to treat them as two sides of the same coin and, erroneously, assume that they are affected by the same set of factors. Serven and Nguyen (2010) found that two views exist about the causes of external imbalances. The first one - the disequilibrium approach - concentrates on current accounts (a current account affects a capital account, and the balance of the former is - using their word - a goods phenomenon). The other one - the equilibrium approach - puts capital accounts at the centre of the analysis (a current account is affected by a capital account, and the balance of the former is an asset phenomenon). In this context, my article is the first which analyzed the determinants of both the current account and the capital account.

The aim of the article is to point out both the proximate and fundamental causes of the Eurozone crisis. Bearing this in mind, I gave the text the following structure. The first part briefly describes the crisis. The word "briefly" is crucial I find the description of the Eurozone economic crisis to be only introductory and I recommend to interested readers the vast literature on the economic problems affecting that currency union (see, for example, Boltho and Carlin (2012), Fatas (2013), and Chen, Milesi-Ferretti and Tressel (2012) among others). The second section analyzes the proximate causes and proves that external imbalances should be seen as the reason of the crisis. The third part analyzes the fundamental causes. The final section concludes.

\section{Description of the Eurozone crisis}

The Eurozone crisis started in 2010 when it was revealed that the fiscal position of Greece was vastly different and much weaker than had been presented(the public data about the main fiscal indicators had been manipulated). The new Greek government disclosed the true state of the public finances. In 2009, the budget deficit was equal to about $15 \%$ of GDP and public debt amounted to $130 \%$ of GDP. The sentiments of investors dramatically worsened and it made Greece unable to roll over its debt.

At the same time, the financial markets put huge pressure on other so-called periphery countries. Those members of the Eurozone experienced a sudden stop in private capital flows. That situation led to problems with those countries' liquidity, making them so desperate that they had to use external, non-market sources of finance - the IMF and other official programs (mainly organized by the European Union). By the end of 2013, five Eurozone countries had used such sources - Greece, Ireland, Portugal, Cyprus and Spain (Spain did so to capitalize its troubled financial institutions).

Apart from the financial shock, the periphery countries were also hit by serious problems within the real economy. Many of them still struggle with recession, reflected in declines in GDP and increases in unemployment. The crisis also affected 
the political life of member states. Periphery countries in particular experienced a rise in political instability, manifested in frequent changes of governments and the fact that radical parties gained in popularity.

In reaction to the crisis, some measures were implemented to improve the economic situation. Periphery countries took steps to improve their budget balances and debt ratios, and the European Central Bank provided them (although hesitantly at the very beginning of the crisis) with liquidity. The majority of European leaders signed the Fiscal Compact and established a new institutional infrastructure to supervise the financial system of the European Union.

It is worth adding that some economists tend to treat the problems of the $\mathrm{Eu}$ rozone not as one crisis, but as a coexistence of several crises. Shambaugh (2012), for instance, claims that the currency union is being exposed to three interconnected crises: (1) a banking crisis, (2) a sovereign debt crisis and (3) a growth and competitiveness crisis. However, in this article I use the term "crisis" (singular) because these interconnections of sub-crises can be seen as one, though complex, crisis.

\section{Proximate causes of the Eurozone crisis - econometric analysis}

Two views have dominated the debate on the causes of the Eurozone crisis. Some economists indicate that the too expansionary fiscal policy of the periphery countries was the key determinant of the crisis. Others tend to treat external imbalances (seen in the current accounts of member countries) as the main cause. Being aware of that divergent views, one should conduct a careful analysis in order to show why the crisis occurred.

In this section, I describe the econometric analysis. The whole period of the study is 2000-2012. In each estimation, the average (geometric mean) growth rate of GDP in the period 2008-2012 is the dependent variable ${ }^{1}$. It should be stated that I consider only the first 12 members of the Eurozone (the 11 countries that formed the currency area in 1999, and Greece, which joined them in 2001). I excluded "new" member countries to overcome difficulties connected with the fact that in the pre-crisis years they were changing their status (countries outside the ERM II/countries within the EMR II/member countries of the Eurozone). The inclusion of Greece was motivated by several reasons. The first one is trivial - it is the country which initiated the crisis in the currency union. Secondly, although the period of the analysis overlaps with the year when Greece was outside of the Eurozone (2000), it is only one year out of thirteen forming the time frame of the study (hence, the duration of the existence outside of the Eurozone is only a small fraction of the span of the whole analysis). Thirdly, even in 2000 Greece was on the road to joining the currency union. One may conclude that, in that year, Greece was a hidden member of the Eurozone.

\footnotetext{
${ }^{1}$ All data are taken from the OECD database if not stated otherwise.
} 
Tables 1 and 2 present the results of the OLS estimations with two independent variables in each -the current account balance (\% of GDP) and one fiscal factor (budget balance in Table 1, and public debt in Table 2; each as a \% of GDP). Dependent variables are averages (simple mean) for years 2000-2007. That construction should overcome the endogeneity problem.

Table 1. Multiple regression analysis - results of the estimation with budget balance (cross-section)

\begin{tabular}{|c|c|c|c|c|c|c|}
\hline $\begin{array}{l}\text { Independent } \\
\text { Variable }\end{array}$ & Coefficient & $\begin{array}{l}\text { Standard } \\
\text { Error }\end{array}$ & t Statistics & $P>|t|$ & \multicolumn{2}{|c|}{$\begin{array}{l}\text { 95\% Confidence } \\
\text { Interval }\end{array}$} \\
\hline $\begin{array}{l}\text { Cur. account } \\
\text { balance }\end{array}$ & $0.15^{*}$ & 0.07 & 1.98 & 0.08 & -0.02 & 0.32 \\
\hline $\begin{array}{l}\text { Budget } \\
\text { balance }\end{array}$ & 0.02 & 0.16 & 0.11 & 0.92 & -0.35 & 0.38 \\
\hline Constant term & $-0.69^{*}$ & 0.36 & -1.90 & 0.09 & -1.50 & 0.13 \\
\hline Source & SS & df & MS & \multicolumn{2}{|l|}{ Statistic } & Value \\
\hline $\begin{array}{l}\text { Model } \\
\text { Residual } \\
\text { Total }\end{array}$ & $\begin{array}{r}9.15 \\
11.96 \\
21.12\end{array}$ & $\begin{array}{r}2 \\
9 \\
11\end{array}$ & $\begin{array}{l}4.58 \\
1.33 \\
1.92\end{array}$ & \multicolumn{2}{|c|}{$\begin{array}{l}\text { Number } \\
\text { of observations } \\
\text { F(2.9) } \\
\text { Prob> F } \\
\text { R-squared } \\
\text { Adjusted R-squared } \\
\text { Root MSE }\end{array}$} & $\begin{array}{l}12 \\
3.44 \\
0.08 \\
0.43 \\
0.31 \\
1.15\end{array}$ \\
\hline
\end{tabular}

Source: author's own elaboration.

Table 2. Multiple regression analysis - results of the estimation with public debt (cross-section)

\begin{tabular}{|l|c|c|c|c|c|c|}
\hline $\begin{array}{l}\text { Independent } \\
\text { Variable }\end{array}$ & Coefficient & $\begin{array}{c}\text { Standard } \\
\text { Error }\end{array}$ & $\mathrm{t}$ Statistics & $\mathrm{P}>|\mathrm{t}|$ & \multicolumn{2}{|c|}{$\begin{array}{c}\text { 95 Confidence } \\
\text { Interval }\end{array}$} \\
\hline $\begin{array}{l}\text { Cur. account } \\
\text { balance }\end{array}$ & $0.14^{*}$ & 0.07 & 2.21 & 0.05 & -0.00 & 0.29 \\
\hline Public debt & 0.00 & 0.13 & -0.27 & 0.79 & -0.03 & 0.03 \\
\hline Constant term & -0.48 & 0.88 & -0.55 & 0.60 & -2.47 & 1.51 \\
\hline Source & $\mathrm{SS}$ & $\mathrm{df}$ & $\mathrm{MS}$ & Statistic & Value \\
\hline & & & & Number & \\
& & & & of observations & 12 \\
Model & 9.23 & 2 & 4.62 & F(2.9) & 3.50 \\
Residual & 11.88 & 9 & 1.32 & Prob> F & 0.08 \\
Total & 21.11 & 11 & 1.92 & R-squared & 0.44 \\
& & & & Adjusted R-squared & 0.31 \\
& & & & Root MSE & 1.15 \\
\hline
\end{tabular}

Source: author's own elaboration.

The results suggest that the fiscal positions of the member countries were statistically insignificant in explaining the economic activity of those countries during the crisis. At the same time, the current account balance remains statistically 
significant. One gets similar results conducting simple regressions. Figure 1 shows the results when an average budget balance is an independent variable. It is evident that such a model lacks explanatory power (R-squared equals 0.19 ). It is also easy to recognize that Greece is an outlier. When that country is excluded, R-squared falls to 0.007 and the sign of the relationship between variables turns negative (Figure 2). In both estimations, budget deficit remains statistically insignificant.

Figure 1. Simple regression analysis - results of the estimation with budget balance (cross-section)

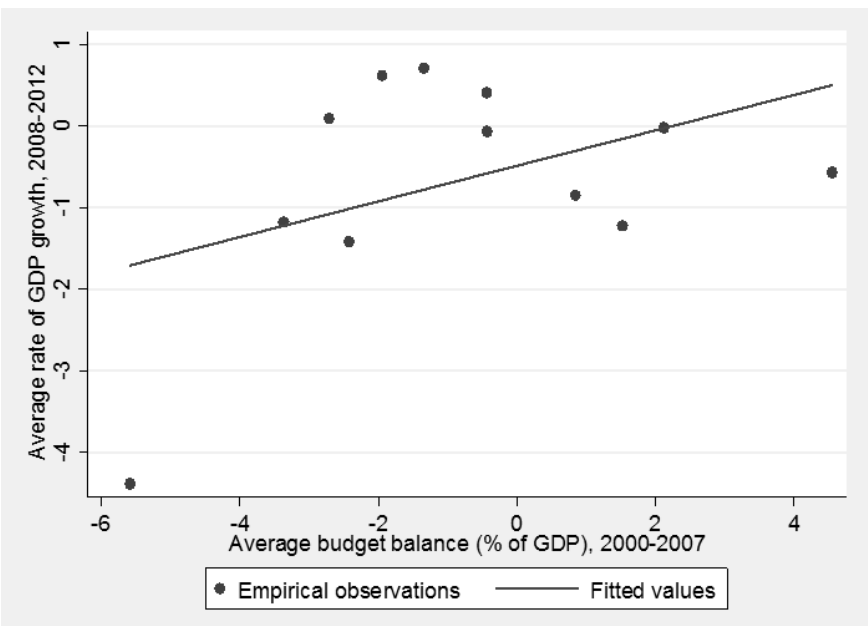

Source: author's own elaboration.

Figure 2. Simple regression analysis - results of the estimation with budget balance (excluding Greece, cross-section)

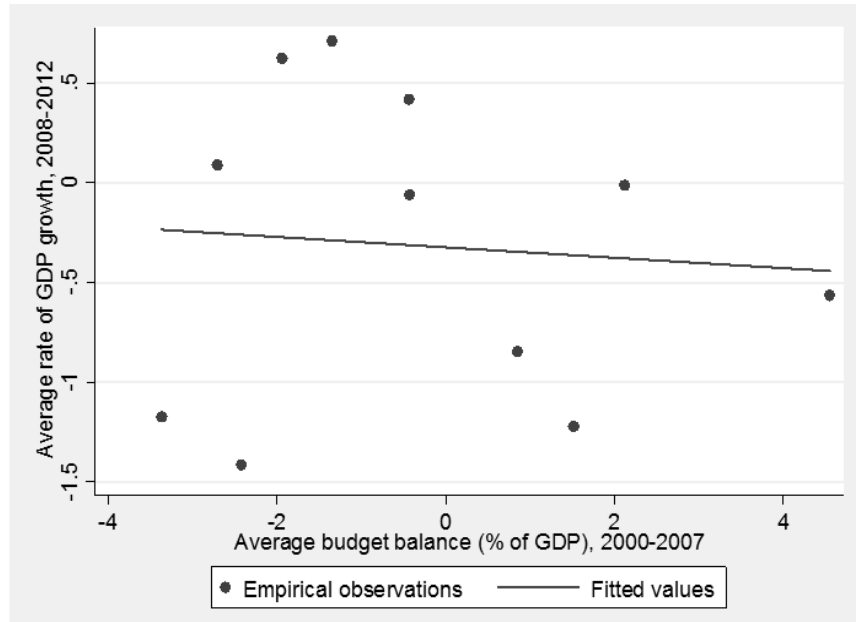

Source: author's own elaboration. 
Simple regressions with public debt follow a similar pattern. As Figure 3 shows, one country (Greece) is an outlier and seriously affects the results. However, even those results can hardly stand as evidence that high public debt in pre-crisis times caused the more severe fall in GDP during 2008-2012 (R-squared takes the value of 0.13 ). Figure 4 present the results when Greece is excluded. There is no evidence that countries other than Greece were hit harder when they had higher public debt (with an R-squared of merely 0.0005). As with budget balance, the ratio of public debt to GDP is statistically insignificant.

Figure 3. Simple regression analysis - results of the estimation with public debt (cross-section)

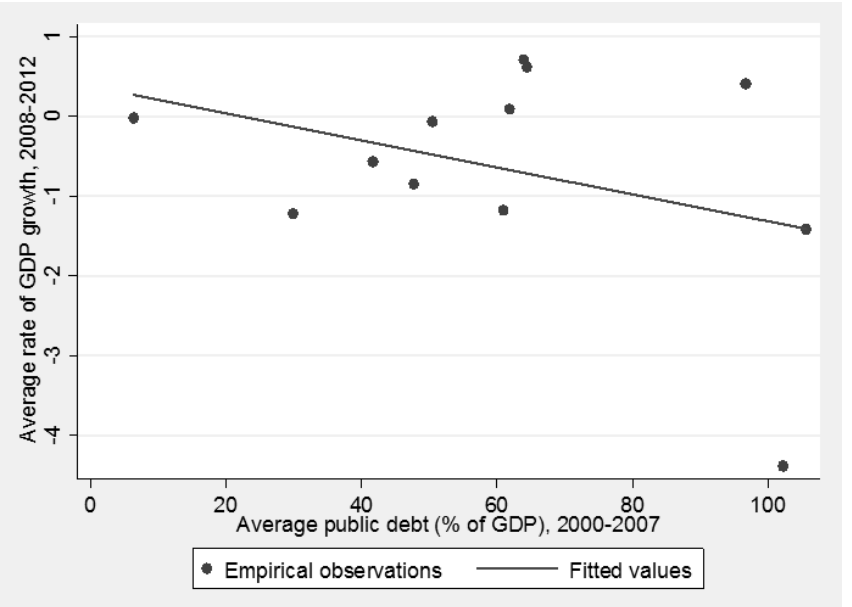

Source: author's own elaboration.

Figure 4. Simple regression analysis - results of the estimation with public debt (excluding Greece, cross-section)

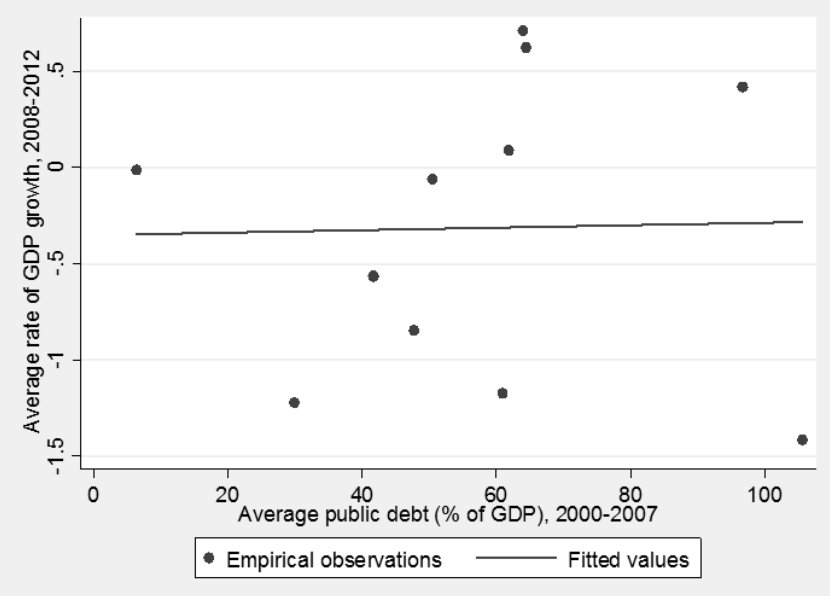

Source: author's own elaboration. 
Having presented the results of simple regressions with fiscal factors, I think that the main conclusion is rather clear. The data does not support the notion that the too expansionary fiscal policy of periphery countries in the pre-crisis period is responsible for the occurrence of the crisis. At the same time, those results should not be seen as evidence that an unbalanced budget or high public debt are favourable to economic growth. What is needed is some scepticism that fiscal austerity may be a proper solution to the problems of the Eurozone member countries. To put that statement in another perspective: assuming that the results of estimations including Greece held, if an average periphery country were to experience the decline of GDP at half of the actual rate, it should have public debt lower by 53\% of GDP (it is equivalent to the public debt amounting to only $16 \%$ of GDP - rather questionable and improbable). Those results are not surprising when one compares, for example, Germany (the best-performing Eurozone economy during the crisis) to Spain and Ireland (countries experiencing sharp recessions). The former had, on average, a budget deficit equal to $1.3 \%$ of GDP in 2000-2007 and public debt of $64 \%$ of GDP. Spain (Ireland) had a budget surplus of $0.84 \%$ (1.5\%)of GDP and public debt of $47.7 \%$ (29.9\%) of GDP.

In contrast to fiscal factors, the current account balance is a better predictor of economic activity. Figure 5 shows that a rather strong relationship exists between that balance and GDP growth among Eurozone countries. It is seen in the statistical significance of that variable and the value of R-squared (0.43). The results change only slightly when one excludes Greece (for example, R-squared drops to 0.33). They are illustrated in Figure 6.

Figure 5. Simple regression analysis - results of the estimation with current account balance (cross-section)

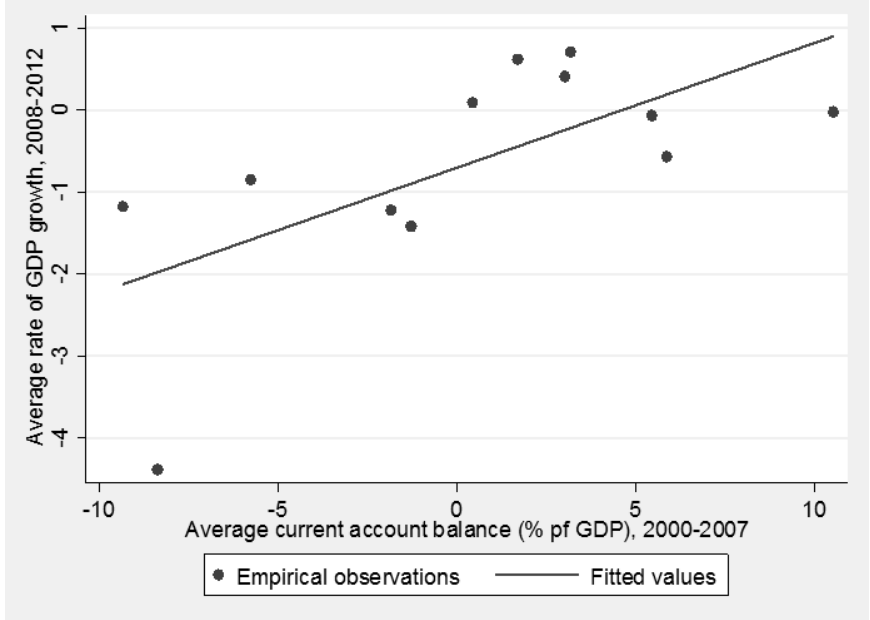

Source: author's own elaboration. 
Figure 6. Simple regression analysis - results of the estimation with current account balance (excluding Greece, cross-section)

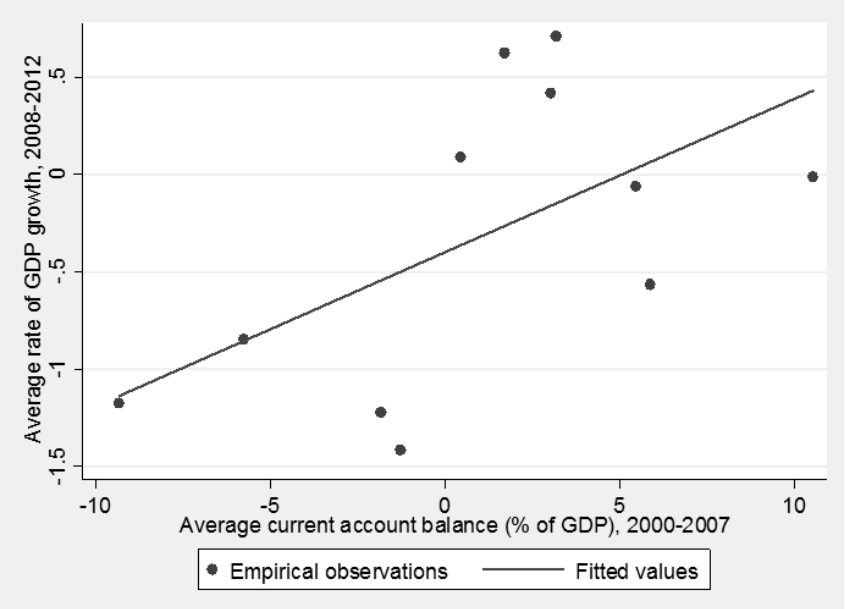

Source: author'sownelaboration.

\section{Fundamental causes of the Eurozone crisis - econometric analysis}

The results presented in Section 2 prove that the balance of payments is where one should search for the fundamental causes of the crisis. The pre-crisis current account balance is a good determinant of countries' economic activity during the 2008-2012 period (using both simple and multiple regression). However, balance of payments identity makes matters more complicated than it seems prima facie. Because the current account may reflect the capital account (with the reverse sign), it is debatable whether it is the former or the latter which determined the differences in economic activity across the Eurozone countries.

One possibility is that the current account deficits of periphery countries had to be financed by the inflow of foreign capital (capital account surplus), hence, prolonged deficits led to increasing foreign debt with adverse consequences in the future. Using that perspective, researchers should treat the determinants of the current account as the fundamental causes of the crisis. Since the mentioned deficits may be a result of the lack of international competitiveness (depressed exports), many economist consider the crisis in the Eurozone to be a manifestation of that low competitiveness. According to the most popular opinion, it is the discrepancy between wages (growing faster) and labour productivity (growing slower) that makes the Eurozone periphery unsuccessful on international markets. Among the advocates of that view one may include Boltho and Carlin (2012) and Shambaugh (2012). 
Alternative (but less popular) scenarios are also presented. What they have in common is the focus on the capital account. Reis (2013) built a model in which failures of the financial market lead to a misallocation of foreign capital in favour of unproductive sectors (like real estate). In that view, capital flows result in lower aggregate productivity and competitiveness of countries, and not the opposite. So it seems that movements of capital are not only a reflection of the necessity to finance the current account. Caballero, Fahri and Gourinchas (2008) presented a model which generates similar result, however, the mechanism is very different. Their paper explains the phenomenon of the so called global imbalances. They suggested that the global economy is characterized by an insufficient supply of safe, high-quality financial assets. Excessive demand for such assets makes capital flow to countries-issuers. The change in investors' sentiments may lead to a sudden stop, an increase in interest rates, and financial and economic crisis. Carroll and Jeanne (2009) pointed out that the demand for foreign assets is determined by precautionary motives and influenced by a country's safety net. In countries with weak safety nets, people save more and those savings are invested abroad. Each of these mechanisms generates a flow of capital which could be manifested in a current as well as a capital account.

In my econometric analysis, I try to reconcile both views in order to find fundamental causes of the crisis. My research is based on panel data regressions in which the current account balance in the 2000-2007 period plays the role of dependent variable. One of the independent variables is the divergence between growth of wages and growth of labour productivity. Ceteris paribus, the bigger that divergence, the lower the competitiveness and the lower current account balance. Another regressor is the ratio of social spending to GDP ${ }^{3}$. Intuitively, all else being equal, the higher that ratio, (1) the lower the competitiveness, or (2) the lower the precautionary savings. Both mechanism should lead to a deterioration of the current account balance.

The latter link between social spending and current account is taken from Carroll and Jeanne (2009). However, I skipped other potential determinants of capital flows pointed out by Caballero, Fahri and Gourinchas (2008). Firstly, their model is constructed to capture the economic relations between Anglo-Saxon countries (mainly the USA) and many non-European states (emerging markets, oil producers and newly industrialized countries of East Asia). Since Europe plays a marginal role in their analysis, the model is incapable of describing phenomena within the Eurozone. Secondly, the authors give a rationale for the movement of capital in the direction of issuers of high-quality financial assets. If one claims that a similar situation was present in the Eurozone, one must assume that periphery countries (the destination of capital flows) produce safer assets than core countries (the origin of the capital). The

\footnotetext{
${ }^{2}$ Data on wages, labor productivity and social spending are taken from the OECD database.
} 
traditional benchmark in Europe are German bonds, not Greek or Spanish ones. Even if that perception has changed, there is no evidence that periphery countries were seen in 2000-2007 as safer and more reliable issuers of financial instruments than Germany or the Netherlands. The spreads on bonds of the Eurozone countries converged but it was the result of the underestimation of risk (driven by, for example, the failures of rating agencies). In no case is it an indicator of higher quality of asset issued by the peripheries.

In the econometric analysis, I include other potential determinants of the current account (and capital account reflected in the balance of the former one). One of them is the rate of return on assets of the banking sector. Intuitively, the higher that rate, the larger the capital inflows and the lower the current account balance (ceteris paribus). Another regressor is the ratio of overhead costs to the banking sector's assets. I expect the sign of its coefficient to be positive for two reasons. Firstly, a high ratio means that the financial market in a given country is too small to provide banks with the opportunity to exploit economies of scale. In these circumstances, those institutions should increase their foreign operations and it should be reflected in the capital outflow from the country (an improvement of the current account).

Secondly, the empirical literature indicates that large financial institutions are less efficient than their smaller competitors. Berger and Mester (1997) found that many US banks operate above their technological optimum - they are bigger than is justified by the average cost (which was minimal for banks with assets of 25 bln USD). Amel, Barnes, Panetta and Salleo (2004) found that in North America and Europe, there is a U-shaped relationship between the size of bank and its ratio of operating costs to revenues ${ }^{3}$. Hence, one may assume that big banks operate abroad due not to their high efficiency, but for strategic reasons. Countries where the decisions of banks are motivated by strategic considerations experience an outflow of capital and a better balance of the current account. Logically, the higher the concentration of the banking sector, and the higher the importance of systemic banks (so called Too-Big-To-Fail, or TBTF banks), the more important the strategy is in the decisions of financial institutions (while efficiency pales into insignificance). In the European Union that problem is observable (Table 3 and Table 4) and it justifies the negative association between the overhead costs of banks and capital flows 4 .

\footnotetext{
${ }^{3}$ For example, in Europe the ratio was $63.1 \%$ for banks with assets lower than 5 bln USD, $61.6 \%$ for banks with assets in the range between 5 and 20 bln USD, 55.6\% for banks with assets in the range between 20 and 50 bln USD and $65.5 \%$ for banks with assets higher than 50 bln USD.

${ }^{4}$ Ferreira (2012) showed that concentration of the banking sector led to lower efficiency of financial institutions in the European Union in 1998-2008.
} 
Table 3. Characteristics of systemically large banks in the Eurozone members in 2008

\begin{tabular}{|l|c|c|c|c|c|c|}
\hline \multirow{2}{*}{ Country } & \multicolumn{2}{|c|}{ Liabilities (divided byGDP) } & \multicolumn{4}{|c|}{$\begin{array}{c}\text { Number of banks with liabilities exceeding } \\
\text { the following threshold }\end{array}$} \\
\cline { 2 - 7 } & Sum & Maximum & $\begin{array}{c}10 \% \text { of } \\
\text { GDP }\end{array}$ & $\begin{array}{c}25 \% \text { of } \\
\text { GDP }\end{array}$ & $\begin{array}{c}50 \% \text { of } \\
\text { GDP }\end{array}$ & $\begin{array}{c}100 \% \text { of } \\
\text { GDP }\end{array}$ \\
\hline Austria & 2.132 & 0.555 & 6 & 4 & 1 & 0 \\
\hline Belgium & 2.916 & 1.904 & 3 & 2 & 1 & 0 \\
\hline Finland & 0.181 & 0.166 & 1 & 0 & 0 & 0 \\
\hline France & 2.737 & 1.042 & 4 & 4 & 3 & 1 \\
\hline Germany & 1.350 & 0.870 & 2 & 1 & 1 & 0 \\
\hline Greece & 1.482 & 0.390 & 5 & 3 & 0 & 0 \\
\hline Ireland & 2.393 & 0.991 & 3 & 3 & 3 & 0 \\
\hline Italy & 1.432 & 0.631 & 3 & 2 & 1 & 0 \\
\hline Luxembourg & 0.023 & 0.023 & 0 & 0 & 0 & 0 \\
\hline Netherlands & 2.469 & 2.218 & 2 & 1 & 1 & 1 \\
\hline Portugal & 1.217 & 0.538 & 3 & 2 & 1 & 0 \\
\hline Spain & 1.749 & 0.910 & 3 & 2 & 1 & 0 \\
\hline
\end{tabular}

Source: Demirguc-Kunt and Huizinga (2010), p. 34 (Table 3; modified).

Table 4. Ratio of combined assets of the three or five largest banks to GDP

\begin{tabular}{|l|c|c|c|c|c|c|}
\hline \multirow{2}{*}{ Country } & \multicolumn{3}{|c|}{ Top 3 banks } & \multicolumn{3}{c|}{ Top 5 banks } \\
\cline { 2 - 7 } & 1990 & 2006 & 2009 & 1990 & 2006 & 2009 \\
\hline Germany & 38 & 117 & 118 & 55 & 161 & 151 \\
\hline UK & 68 & 226 & 336 & 87 & 301 & 466 \\
\hline France & 70 & 212 & 250 & 95 & 277 & 344 \\
\hline Italy & 29 & 110 & 121 & 44 & 127 & 138 \\
\hline Spain & 45 & 155 & 189 & 66 & 179 & 220 \\
\hline Netherlands & 154 & 538 & 406 & 159 & 594 & 464 \\
\hline Sweden & 89 & 254 & 334 & 120 & 312 & 409 \\
\hline Japan & 36 & 76 & 92 & 59 & 96 & 115 \\
\hline USA & 8 & 35 & 43 & 11 & 45 & 58 \\
\hline
\end{tabular}

Source: Goldstein and Veron (2011), p. 39 (Table 2). 
Other explanatory variables are the percentage of foreign banks among total banks, budget balance (\% of GDP), index of legal institutional quality and two dummy variables 5 . The presence of foreign banks may influence both trade (through facilitating international expansion of firms - improvement of current account balance) and capital flows (through financial expansion in the destination country - worsening of current account balance). Including budget balance into the regression is justified due to the possibility of the twin deficits phenomenon (thus, one should expect a positive sign of the coefficient). Although fiscal factors do not play an important role as stand-alone determinant of the crisis, it is reasonable that they indirectly (through balance of payments) influenced economic activity across the Eurozone members. The index of legal institutional quality is introduced to quantify the impact of legal obstacles on the operations of companies. Ceteris paribus, its increase should result in an improvement of the current account balance.

The two dummy variables are: (1) the core of the European Union (1 for the six initial members of the European Community; 0 - otherwise), and (2) the South of the Eurozone ( 1 for France, Greece, Italy, Spain and Portugal). The first dummy variable captures all the stable factors influencing patterns of trade and capital flows within the currency union. The core of the European Union may be more integrated and economically advanced (due to their involvement in European integration since the 1950s). It may lead to a tendency of those countries to export capital (and maintain current account surpluses). The second dummy captures institutional and cultural differences between Southern and Northern members of the Eurozone. They may make Southern (Northern) states more inclined to borrow (lend) capital - for instance, due to differences in intertemporal preferences over current and future consumption. It must be stated that, although I name that variable "South", I do not treat it as completely exogenous (the name "South" is given for reasons of simplicity). Facing capital inflows, a country may change its regulations and/or nations may gradually modify their behaviour.

During the analysis I used two estimators which are frequently used in panel data analyses: Hausman-Taylor (HT) and Amemiya-MaCurdy (AM) estimators. Both demand the division of dependent variables into four categories due to their stability in time (time-variant and time-invariant determinants - TV and TI, respectively) and endogeneity (endo- and exogenous determinants). Table 5 places regressors into those four groups.

\footnotetext{
${ }_{5}^{5}$ Sources of data: percentage of foreign banks among total banks - Claessens and van Horen (2012), budget balance - OECD database, legal institutional quality - Aljaz Kuncic's institutional quality dataset (available on-line).
} 
Table 5. Classification of dependent variables

\begin{tabular}{|l|l|l|l|}
\hline \multicolumn{2}{|l|}{ Criterion } & \multicolumn{2}{|l|}{ Stability in time } \\
\cline { 2 - 4 } & \multicolumn{2}{|l|}{ Time-variant variables } & Time-invariant variables \\
\hline \multirow{2}{*}{ Endogeneity } & $\begin{array}{l}\text { Endogenous } \\
\text { variables }\end{array}$ & $\begin{array}{l}\text { late of return } \\
\text { overhead costs } \\
\text { divergence } \\
\text { budget balance }\end{array}$ & south \\
\cline { 2 - 4 } & $\begin{array}{l}\text { Exogenous } \\
\text { variables }\end{array}$ & $\begin{array}{l}\text { foreig banks } \\
\text { legal quality }\end{array}$ & core \\
\hline
\end{tabular}

Source: author's own elaboration.

Tables 6 and 7 present the results of the estimations. Both are quantitatively similar. The only exception is that when using the HT estimator, one finds the dummy "South" statistically significant, and while using the AM estimation technique, one is left with a different result. According to both estimations, variables statistically influencing member states' current accounts during the 2000-2007 period were: (1) quality of legal institutions, (2) ratio of overhead costs to assets of the banking sector, (3) being one of the core countries and (4) status of being a Southern country (but only using HT estimator). Those variables also have expected signs. Table 8 summarizes the results by comparing the values of the coefficients.

Table 6. Panel data analysis - HT estimator

\begin{tabular}{|l|c|c|c|c|c|c|}
\hline $\begin{array}{l}\text { Independent } \\
\text { Variable }\end{array}$ & Coefficient & $\begin{array}{c}\text { Standard } \\
\text { Error }\end{array}$ & $\mathrm{t}$ Statistics & $\mathrm{P}>|\mathrm{t}|$ & \multicolumn{2}{|c|}{$\begin{array}{c}\text { 95 Confidence } \\
\text { Interval }\end{array}$} \\
\hline Foreign banks & -0.07 & 0.05 & -1.46 & 0.14 & -0.16 & 0.02 \\
\hline Legal quality & 5.86 & 1.58 & 3.72 & 0.00 & 2.77 & 8.95 \\
\hline Rate of return & -0.45 & 0.50 & -0.90 & 0.37 & -1.44 & 0.54 \\
\hline Overhead costs & 1.17 & 0.38 & 3.06 & 0.00 & 0.42 & 1.92 \\
\hline Divergence & 0.18 & 0.11 & 1.58 & 0.11 & -0.04 & 0.40 \\
\hline Budget balance & 0.03 & 0.15 & 0.22 & 0.83 & -0.26 & 0.32 \\
\hline Core & 5.77 & 3.16 & 1.83 & 0.07 & -0.42 & 11.96 \\
\hline Periphery & -7.75 & 4.49 & -1.73 & 0.08 & -16.56 & 1.05 \\
\hline Constant term & -5.68 & 4.65 & -1.22 & 0.22 & -14.80 & 3.44 \\
\hline
\end{tabular}




\begin{tabular}{|l|l|l|l|}
\hline Number of: & & Sigma u & 4.91 \\
• observations & 96 & Sigma e & 1.70 \\
• groups & 12 & Rho & 0.89 \\
Observations & & & \\
per group: & & & \\
• minimum & 8 & & \\
- average & 8 & & \\
- maximum & 8 & & \\
Random effects u & i..i.d. & & \\
Wald chi2(8) & 44.82 & & \\
Prob $>$ chi2 & 0.00 & & \\
\hline
\end{tabular}

Source: author's own elaboration.

Table 7. Panel data analysis - AM estimator

\begin{tabular}{|c|c|c|c|c|c|c|}
\hline $\begin{array}{l}\text { Independent } \\
\text { Variable }\end{array}$ & Coefficient & $\begin{array}{l}\text { Standard } \\
\text { Error }\end{array}$ & t Statistics & $P>|t|$ & \multicolumn{2}{|c|}{$\begin{array}{l}95 \% \text { Confidence } \\
\text { Interval }\end{array}$} \\
\hline Foreign banks & -0.06 & 0.04 & -1.33 & 0.18 & -0.15 & 0.03 \\
\hline Legal quality & 6.09 & 1.54 & 3.96 & 0.00 & 3.08 & 9.11 \\
\hline Rate of return & -0.43 & 0.50 & -0.87 & 0.39 & -1.42 & 0.55 \\
\hline Overhead costs & 1.18 & 0.38 & 3.09 & 0.00 & 0.43 & 1.92 \\
\hline Divergence & 0.17 & 0.11 & 1.54 & 0.12 & -0.05 & 0.39 \\
\hline Budget balance & 0.07 & 0.14 & 0.46 & 0.65 & -0.22 & 0.35 \\
\hline Core & 5.99 & 3.14 & 1.91 & 0.06 & -0.16 & 12.14 \\
\hline Periphery & -6.03 & 3.67 & -1.64 & 0.10 & -13.23 & 1.17 \\
\hline Constant term & -7.02 & 4.21 & -1.67 & 0.10 & -15.27 & 1.23 \\
\hline $\begin{array}{l}\text { Number of: } \\
\text { - observations } \\
\text { - groups }\end{array}$ & \multicolumn{3}{|l|}{$\begin{array}{l}96 \\
12\end{array}$} & $\begin{array}{l}\text { Sigma u } \\
\text { Sigma e } \\
\text { Rho }\end{array}$ & \multirow{3}{*}{\multicolumn{2}{|c|}{$\begin{array}{l}5.21 \\
1.75 \\
0.90\end{array}$}} \\
\hline $\begin{array}{l}\text { Observations } \\
\text { per group: } \\
\text { - minimum } \\
\text { - average } \\
\text { - maximum }\end{array}$ & $\begin{array}{l}8 \\
8 \\
8\end{array}$ & & & & & \\
\hline $\begin{array}{l}\text { Random effects } u_{i} \\
\text { Wald chi2 }(8) \\
\text { Prob > chi2 }\end{array}$ & $\begin{array}{r}\text { i..i.d. } \\
47.19 \\
0.00\end{array}$ & & & & & \\
\hline
\end{tabular}

Source: author's own elaboration. 
Table 8. Comparison of coefficients - HT and AM estimators

\begin{tabular}{|l|c|c|}
\hline Dependent variable & HT estimator & AM estimator \\
\hline Foreign banks & -0.07 & -0.06 \\
\hline Legal quality & $5.86^{* * *}$ & $6.09^{* * *}$ \\
\hline Rate of return & -0.45 & -0.43 \\
\hline Overhead costs & $1.17^{* * *}$ & $1.18^{* * *}$ \\
\hline Divergence wages-productivity & 0.18 & 0.17 \\
\hline Budgest balance & 0.03 & 0.07 \\
\hline Core & $5.77^{*}$ & $5.99^{*}$ \\
\hline South & $-7.75^{*}$ & -6.03 \\
\hline Constant term & -5.68 & -7.02 \\
\hline
\end{tabular}

Source: author's own elaboration.

The results of the mentioned estimations shed some light on the actions taken by Eurozone members (at national and supranational level) to tackle the crisis. It seems that budget deficits remain irrelevant as the source of the financial and economic problems of the currency union. Not only is budget balance statistically insignificant in the estimations presented in Section 2 (in which that variable could directly affect GDP growth), but also it stays insignificant as an indirect (via current or capital account) determinant of the economic activity in member states. Hence, fiscal austerity may be seen as an inappropriate measure to resolve the crisis. The divergence between wages and productivity dynamics is also insignificant. That result questions the validity of the frequently claimed need for internal devaluation in the peripheries.

The results of estimations paint a rather gloomy picture of the causes of the crisis. It seems that mainly institutional factors were at play. Without improving the business environment in periphery countries it may be impossible to solve the crisis through austerity or internal devaluation (leading only to mounting social and economic costs of such measures). It also seems that an increase in the ratio of overhead costs to banking sector assets may be efficient in improving the member states' balance of payments and rate of economic growth. One of the ways to do so is to foster competition in the banking sector. It would lead to lower assets of a typical bank and a higher ratio of overhead costs to those assets. The U-shaped relationship between bank size and its efficiency means that it is also possible to increase that ratio through higher concentration of the financial sector. However, it may lead to more moral hazard practices (due to problems of the TBTF banks). That is why the optimal path of banks increasing their overhead 
costs is by intensifying competition on the financial market. At the same time, the core countries should try to make their financial institutions more efficiency and less strategy-driven (in the context of international expansion). The reforms of financial supervision (aimed at providing the European Union countries with more control over big banks) should be seen as an important (though not sufficient) step forward.

\section{Conclusion}

The Eurozone crisis has been widely debated among economists, politicians, and the media. However, it is surprising that in the search for the causes of the crisis researchers in many cases have not been rigorous enough. The results of their studies have been based on oversimplifications. Many of them assumed that fiscal factors are the reasons of the decline in the Eurozone members' GDP (it is not supported by the data). Others found (correctly) that external imbalances were much more important, but at the same time they assumed that those imbalances were driven by the lack of international competitiveness or factors affecting capital flows. To the best of my knowledge there exist no study investigating both groups of determinants of balance of payments. This article fills this gap.

The results support the so called equilibrium approach to external imbalances. It seems that neither divergence between wages and productivity nor budget balance influenced the current (or capital) accounts of member states. Factors connected with institutional quality or the structure of financial markets were of much greater importance. It means that many measures taken by the Eurozone countries (like fiscal austerity and internal devaluation) were implemented too hastily and led to unnecessary economic and social costs.

\section{Bibliography}

Amel D., Barnes C., Panetta F., Salleo C. (2004), Consolidation and Efficiency in the Financial Sector: A Review of the International Evidence, "Journal of Banking and Finance", No. 28, 2493-2519.

Berger A.N., Mester L.J. (1997), Inside the box: What explains differences in the efficiencies of financial institutions?, "Journal of Banking and Finance", No. 21, 895-947.

Boltho A., Carlin W. (2012), The problems of European monetary union - asymmetric shocks or asymmetric behaviour?, VoxEU.org, 31.03 .2012 (date of access: 20.10.2013). 
Caballero R., Fahri E., Gourinchas P.O. (2008), An Equilibrium Model of "Global Imbalances" and Low Interest Rates, "American Economic Review”, 98 (1), 358-393.

Carroll C., Jeanne O. (2009), A Tractable Model of Precautionary Reserves, Net Foreign Assets, or Sovereign Wealth Funds, NBER Working Paper 15228, Cambridge, MA.

Chen R., Milesi-Ferretti G.M., Tressel T. (2012), External Imbalances in the Euro Area, International Monetary Fund Working Paper 12/236, Washington, DC.

Demirguc-Kunt A., Huizinga H. (2010), Are Banks Too Big to Fail or Too Big to Save? International Evidence from Equity Prices and CDS Spreads, European Banking Center Discussion Paper 2010-59, Tilburg.

Fatas A. (2013), The Euro counterfactual, Antonio Fatas on the Global Economy, http://fatasmihov.blogspot.com/2013/09/the-euro-counterfactual.html (date of access: 16.12.2016)

Ferreira C. (2012), Bank market concentration and efficiency in the European Union: a panel Granger causality approach, School of Economics and Management (Technical University of Lisbon) - Department of Economics Working Paper 03/2012/DE/UECE, Lisbon.

Goldstein M., Veron N. (2011), Too Big to Fail: The Transatlantic Debate, Peterson Institute for International Economics Working Paper 11-12, Washington, DC.

Reis R. (2013), The Portuguese Slump and Crash and the Euro Crisis, Brookings Papers on Economic Activity, spring 2013, Washington, DC.

Serven L., Nguyen H. (2010), Global Imbalances Before and After the Global Crisis, World Bank Policy Research Working Paper 5354, Washington, DC.

Shambaugh J. (2012), The Euro's Three Crises, Brookings Papers on Economic Activity, spring 2012, Washington, DC.

\section{Summary}

The paper examines the causes of the Eurozone crisis - they are divided into two categories: proximate and fundamental causes. Regarding the former, it seems that the current account balance should be seen as a crucial determinant of the GDP dynamics of the Eurozone members during 2008-2012. As far as the fundamental causes are concerned, the financial market structure and institutional quality measures are of the highest explanatory power. Econometric results indicate that measures taken to tackle the crisis (austerity and internal devaluation) may be ineffective in restoring growth and stability.

Keywords: Eurozone, financial crisis, balance of payments 


\section{Streszczenie}

Celem artykułu jest przedstawienie przyczyn kryzysu finansowego w strefie euro w podziale na dwie ich kategorie: przyczyny bezpośrednie i fundamentalne. W odniesieniu do pierwszej z nich saldo rachunku obrotów bieżących powinno być postrzegane jako kluczowa determinanta dynamiki PKB w strefie euro w latach 2008-2012. Z kolei najważniejszymi czynnikami fundamentalnymi okazały się te, które były związane ze strukturą rynku i jakością infrastruktury instytucjonalnej.

Keywords: strefa euro, kryzys finansowy, bilans płatniczy

JEL: E32, F32, F41, H63 